\title{
PENERAPAN MODEL PEMBELAJARAN COOPERATIVE LEARNING TIPE GROUP INVESTIGATION BERBASIS MULTIMEDIA UNTUK MENINGKATKAN HASIL BELAJAR SISWA PADA MATA PELAJARAN SISTEM PENGATURAN REFRIGERASI
}

\author{
Raden I. Saputra', Syamsuri Hasan', Maman Rakhman ${ }^{3}$ \\ Departemen Pendidikan Teknik Mesin, FPTK UPI \\ Jl. Dr. Setiabudhi No.207 Bandung 40154 \\ radenipan92@gmail.com
}

\begin{abstract}
ABSTRAK
Penelitian ini bertujuan untuk mengetahui peningkatan hasil belajar siswa dan aktivitas belajar siswa melalui penerapan model pembelajaran cooperative learning tipe group investigation berbasis multimedia pada mata pelajaran sistem pengaturan refrigerasi. Metode penelitian yang digunakan adalah penelitian tindakan kelas. Penelitian terdiri atas tiga siklus. Teknik sampling yang digunakan adalah purposive sampling dengan sampel kelas XI TP A. Teknik pengumpulan data yang digunakan adalah dokumentasi, soal pre-test, post test dan lembar observasi. Hasil penelitian menunjukkan terjadi peningkatan hasil belajar siswa yang ditunjukkan oleh nilai rata-rata $\mathrm{N}$-Gain pada siklus I yang masuk dalam kategori sedang, siklus II kategori sedang, dan siklus III kategori tinggi. Penerapan model pembelajaran ini menunjukkan bahwa aktivitas belajar siswa meningkat pada setiap siklusnya. Hasil rata-rata persentase aktivitas siswa pada siklus I dalam kategori tinggi, meningkat pada siklus II dan III masuk pada kategori sangat tinggi. Simpulan dari penelitian ini adalah penerapan model pembelajaran cooperative learning tipe group investigation berbasis multimedia meningkatkan hasil belajar siswa dan aktivitas belajar siswa pada mata pelajaran sistem pengaturan refrigerasi.
\end{abstract}

Kata kunci: multimedia, hasil belajar, aktivitas belajar.

\section{PENDAHULUAN}

Kegiatan utama proses pendidikan adalah kegiatan belajar mengajar. Individu yang terlibat dalam proses belajar mengajar diharapkan mengalami perubahan baik dalam bidang pengetahuan, pemahaman, keterampilan, nilai, maupun sikap. Permasalahan dalam proses belajar mengajar diantaranya adalah kegiatan di kelas masih berpusat pada guru (teacher center), dimana guru masih mendominasi proses belajar mengajar dengan menggunakan metode ceramah serta multimedia sebagai media pembelajaran masih jarang digunakan oleh guru. Hal ini menyebabkan siswa menjadi pasif sehingga pembelajaran terasa monoton dan membosankan. Persoalan yang terjadi seperti ini merupakan salah satu faktor yang dapat menyebabkan terhambatnya pencapaian tujuan pembelajaran.

\footnotetext{
${ }^{1}$ Mahasiswa Departemen Pendidikan Teknik Mesin FPTK UPI

${ }^{2}$ Dosen Departemen Pendidikan Teknik Mesin FPTK UPI

${ }^{3}$ Dosen Departemen Pendidikan Teknik Mesin FPTK UPI
} 
Berdasarkan pengalaman yang diperoleh penulis pada saat melaksanakan Program Latihan Profesi (PLP) di SMKN 1 Cimahi, persoalan di atas juga terjadi. Dimana pelaksanaan pembelajaran belum difokuskan pada siswa, sehingga proses komunikasi yang berlangsung adalah satu arah, karena metode yang digunakan oleh guru ialah ceramah dan pemberian tugas. Kemajuan teknologi berupa laptop yang di dalamnya dapat menghadirkan multimedia pun tidak dimanfaatkan untuk menunjang kegiatan pembelajaran, sehingga akhirnya berpengaruh pada hasil belajar yang didapat oleh siswa.

Berdasarkan nilai mata pelajaran sistem pengaturan refrigerasi pada kelas XI TPTU di SMKN 1 Cimahi Tahun Pelajaran 2013/2014 yang bersumber dari dokumentasi nilai ulangan harian mata pelajaran sistem pengaturan refrigerasi SMKN 1 Cimahi, hanya 37\% siswa yang memiliki nilai lebih besar atau sama dengan 75 yang merupakan kriteria kelulusan. Guna meningkatkan hasil belajar siswa tersebut, guru harus memiliki strategi belajar dan menggunakan media pembelajaran yang tepat sehingga siswa dapat belajar secara efektif dalam mencapai tujuan pembelajaran. Oleh sebab itu, penulis berusaha memberikan sebuah solusi berupa suatu model pembelajaran yang dapat dijadikan alternatif untuk mengatasi masalah tersebut. Model pembelajaran yang peneliti terapkan untuk mengatasi masalah ini adalah model pembelajaran cooperative learning tipe group investigation (GI) berbasis multimedia.

Model group investigation melibatkan siswa secara langsung dalam proses belajar. Pembelajaran yang dilakukan membuat suasana saling bekerjasama dan berinteraksi antar siswa dalam kelompok tanpa memandang latar belakang, juga siswa dilatih untuk memiliki kemampuan yang baik dalam berkomunikasi. Model ini dapat melatih siswa untuk menumbuhkan kemampuan berpikir mandiri. Keterlibatan siswa secara aktif dapat terlihat mulai dari tahap pertama sampai tahap akhir pembelajaran.

Seiring dengan kemajuan zaman dan teknologi, laptop bukan hal yang asing lagi untuk dimiliki. Pemanfaatan kepemilikan dari siswa inilah yang digunakan untuk menunjang proses pembelajaran siswa dengan menggunakan model group investigation. Penggunaan multimedia ini dimaksudkan agar siswa mampu memvisualisasikan apa yang dijelaskan dan membuat siswa yang lain tidak jenuh, mengerti dan memahami apa yang dijelaskan, serta termotivasi untuk belajar.

Cooperative learning adalah model pembelajaran dalam kelompok kecil, dengan anggota kelompok 3-5 orang, yang dalam menyelesaikan tugas kelompoknya setiap anggota kelompok 
harus saling kerja sama dan saling membantu untuk memahami materi, sehingga setiap siswa selain mempunyai tanggung jawab individu, tanggung jawab berpasangan, juga mempunyai tanggung jawab dalam berkelompok. Model pembelajaran kooperatif, para siswa akan duduk bersama dalam kelompok yang beranggotakan empat orang untuk menguasai materi yang disampaikan oleh guru (Slavin, 2010). Hal ini menjadikan sebagian besar aktivitas pembelajaran berpusat pada siswa, yakni mempelajari materi pelajaran dan berdiskusi untuk memecahkan masalah.

Group Investigation (GI) merupakan salah satu bentuk model pembelajaran kooperatif yang menekankan pada partisipasi dan aktivitas siswa untuk mencari sendiri materi (informasi) pelajaran yang akan dipelajari melalui bahan yang tersedia, misalnya dari buku pelajaran atau siswa dapat mencari melalui internet. Tipe group investigation memiliki tiga konsep utama, yaitu: penelitian atau enquiri, pengetahuan atau knowledge, dan dinamika kelompok atau the dynamic of the learning group, (Winataputra, 2001).

Multimedia diartikan sebagai gabungan dari banyak media atau setidaknya terdiri lebih dari satu media, yaitu teks, animasi, audio, video, dan menyajikan informasi secara terintegrasi (Warsita, 2008). Teknologi multimedia merupakan salah satu teknologi dalam bidang komputer yang memiliki kemampuan untuk menjadikan media pelajaran lebih lengkap. Multimedia merangkumi berbagai media dalam satu program, sehingga memudahkan guru untuk menyampaikan bahan pembelajaran, siswa merasa dilibatkan dalam proses belajar karena teknologi multimedia menyediakan fasilitas terjadinya intraktifitas.

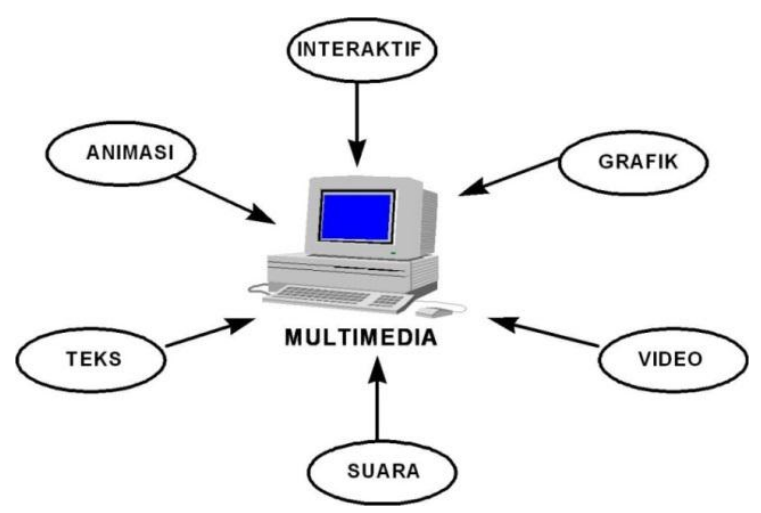

Gambar 1. Konsep Multimedia (Sahuri, 2010)

Multimedia pembelajaran yang akan digunakan dalam peneletian ini adalah multimedia menggunakan laptop sebagai hardware dan program microsoft powerpoint sebagai software yang 
di dalamnya berisi penggabungan dari dua media atau lebih, yaitu antara teks, Gambar, animasi, video dan suara musik instrumen.

Ada beberapa tahapan dalam penerapan tipe group investigation. Ada enam tahapan dalam implementasi teknik group investigation, yaitu 1) mengidentifikasikan topik dan mengatur siswa ke dalam kelompok; 2) merencanakan tugas yang akan dipelajari; 3) melaksanakan investigasi; 4) menyiapkan laporan akhir; 5) mempresentasikan laporan akhir; 6) evaluasi (Syarifuddin, 2011). Penggunaan multimedia dalam menunjang model pembelajaran group investigation ini dilaksanakan pada tahap ketiga sampai kelima.

Tahap ketiga yang tak lain adalah melaksanakan investigasi, siswa menggunakan laptop sebagai alat untuk menampilkan multimedia. Setiap kelompok dibantu dengan menggunakan media gambar dan video/animasi pada laptopnya untuk melakukan analisis informasi. Saat melaksanakan tahap ini, siswa harus mengumpulkan informasi, menganalisis data dan membuat simpulan terkait dengan topik yang diselidiki pada tampilan video.

Tahap keempat, yaitu menyiapkan laporan akhir, anggota kelompok menentukan pesanpesan penting terkait analisis topik yang telah dilakukan dan merencanakan apa yang akan mereka laporkan. Hal ini dituangkan dalam pembuatan powerpoint untuk keperluan presentasi. Media yang dijadikan bahan penganalisisan harus disertakan dalam powerpoint. Multimedia yang digunakan untuk menunjang proses pembelajaran dibatasi pada penggabungan dua sampai tiga media, diantaranya teks, grafik, video atau animasi.

Tahap kelima yang merupakan tahap presentasi, setiap kelompok bergantian ke depan kelas untuk menyajikan hasil diskusinya dengan menggunakan bantuan laptop sebagai alat untuk menyajikan informasi. Multimedia dalam pembelajaran ini digunakan untuk menyalurkan pesan, yaitu materi pembelajaran yang dapat merangsang pikiran, perasaan perhatian dan kemauan belajar. Sehingga diharapkan siswa dapat mengerti dan memahami materi pembelajaran.

Adanya suatu proses belajar akan menghasilkan pula suatu hasil dari proses tersebut yang disebut hasil belajar. Hasil belajar merupakan terjadinya perubahan tingkah laku pada diri siswa yang dapat diamati dan diukur dalam bentuk perubahan pengetahuan sikap dan keterampilan (Hamalik, 2003). Klasifikasi hasil belajar dalam tiga ranah yang dikenal dengan taksonomi bloom, yaitu ranah kognitif, afektif dan psikomotor (Sudjana, 2005).

Mata pelajaran sistem pengaturan refrigerasi merupakan mata pelajaran produktif pada kompetensi keahlian Teknik Pendingin dan Tata Udara di SMKN 1 Cimahi. Penelitian ini 
menggunakan model pembelajaran cooperative learning tipe group investigation berbasis multimedia dengan standar kompetensi memelihara alat penukar kalor pada peralatan refrigerasi komersial dengan kompetensi dasar memahami prinsip pemeliharaan alat penukar kalor pada peralatan refrigerasi komersial, melaksanakan pemeriksaan dalam rangka pemeliharaan alat penukar kalor pada peralatan refrigerasi komersial dan memelihara cooling tower.

\section{METODE PENELITIAN}

Metode penelitian yang digunakan pada penelitian ini adalah metode penelitian tindakan kelas. Penelitian tindakan kelas merupakan penelitian yang dilakukan oleh guru untuk memperbaiki proses pembelajaran di kelas dengan jalan merefleksikan hasil pengamatan yang didapatkan selama penelitian ke dalam bentuk tindakan. Prosedur penelitian tindakan kelas ini terdiri dari 4 tahap, yakni penyusunan rencana, tindakan, observasi dan refleksi. Jumlah siklus dalam penelitian ini adalah 3 siklus. Setiap siklusnya dilakukan satu kali tatap muka pembelajaran (Kunandar, 2012).

Penelitian ini dilaksanakan di SMK Negeri 1 Cimahi yang beralamat di Jalan Mahar Martanegara Nomor 48, Leuwigajah Kota Cimahi. Populasi yang digunakan oleh penulis adalah siswa SMKN 1 Cimahi Jurusan Teknik Pendingin dan Tata Udara tahun ajaran 2013/2014. Teknik sampling yang digunakan adalah purposive sampling dengan sampel kelas XI TP A.

Instrumen yang digunakan penulis dalam penelitian ini adalah observasi yang meliputi observasi terhadap aktivitas siswa dan guru, dokumentasi, pre-test dan post-test. Guna mendapatkan data yang akurat, instrumen yang telah dibuat perlu dilakukan pengembangan dengan menguji instrumen agar memiliki ketepatan dan ketetapan yang baik. Pengujian instrumen lembar observasi adalah dengan melakukan judgment experts, yaitu dengan meminta evalusi dari seorang ahli terhadap panduan yang dibuat. Sementara itu, pengujian instrumen tes meliputi uji validitas, reliabilitas, tingkat kesukaran dan daya pembeda.

Teknik analisis data yang dilakukan adalah dengan menilai hasil belajar siswa aspek kognitif. Mengukur peningkatan hasil belajar siswa setelah dilakukannya pembelajaran dengan mempergunakan Gain Ternormalisasi (N-Gain). Selain itu dilakukan pula penilaian terhadap aktivitas belajar siswa dan keterlaksanaan model pembelajaran. 


\section{HASIL PENELITIAN}

Hasil belajar digunakan untuk melihat kemampuan siswa sebelum dan sesudah dilakukan treatment berupa model pembelajaran cooperative learning tipe group investigation berbasis multimedia. Data tersebut terbagi menjadi nilai rata-rata pre test dan post test. Nilai yang didapat siswa pada saat pre test dan post test siklus I, II, dan III diperoleh rata-rata nilai (Tabel 1).

Tabel 1. Rata-Rata Nilai Pre Test dan Post Test

\begin{tabular}{cccccc}
\hline Siklus & $\begin{array}{c}\text { Rata-rata } \\
\text { Nilai Pre } \\
\text { Test }\end{array}$ & Kategori & $\begin{array}{c}\text { Rata-rata } \\
\text { Nilai Post } \\
\text { Test }\end{array}$ & Kategori & $\begin{array}{c}\text { Kenaikan } \\
\text { Rata-rata } \\
\text { Nilai }\end{array}$ \\
\hline I & 51,56 & Belum Lulus & 81,88 & Lulus Baik & 30,31 \\
\hline II & 52,50 & Belum Lulus & 85,00 & Lulus Baik & 32,50 \\
\hline III & 45,17 & Belum Lulus & 85,86 & Lulus Baik & 40,69 \\
\hline
\end{tabular}

Berdasarkan rekapitulasi perhitungan mengenai data nilai $\mathrm{N}$-Gain ternormalisasi, maka diperoleh rata-rata nilai $N$-Gain (Tabel 2) disetiap siklusnya.

Tabel 2. Rata-Rata Nilai N-Gain Setiap Siklus

\begin{tabular}{ccc}
\hline Siklus & Rata-Rata Nilai $N$-Gain & Kategori \\
\hline I & 0,63 & Sedang \\
\hline II & 0,68 & Sedang \\
\hline III & 0,74 & Tinggi \\
\hline
\end{tabular}

Hasil perhitungan nilai rata-rata $\mathrm{N}$-Gain siklus I, II, dan III mengalami peningkatan, hal tersebut dibuktikan dengan adanya peningkatan nilai gain ternormalisasi dari siklus pertama hingga siklus ketiga dari kategori sedang menuju kategori tinggi. Data ini menunjukkan bahwa adanya keberhasilan dalam perbaikan proses pembelajaran yang terjadi pada siklus II dan III serta menunjukkan juga bahwa penerapan model pembelajaran cooperative learning tipe group investigation berbasis multimedia pada mata pelajaran sistem pengaturan refrigerasi dapat meningkatkan hasil belajar.

Aktivitas belajar siswa merupakan kegiatan siswa terhadap pembelajaran yang diberikan guru dengan aspek penilaian yang telah ditentukan sebelumnya. Berdasarkan rekapitulasi perhitungan mengenai nilai persentase aktivitas belajar siswa, maka diperoleh besar rata-rata nilai persentase aktivitas belajar siswa (Tabel 3) di setiap siklusnya.

Tabel 3. Perkembangan Aktivitas Belajar Siswa

\begin{tabular}{ccc}
\hline Siklus & Persentase & Kategori \\
\hline I & 69,73 & Tinggi \\
\hline
\end{tabular}




\begin{tabular}{ccc}
\hline II & 82,56 & Sangat Tinggi \\
\hline III & 85,48 & Sangat Tinggi \\
\hline
\end{tabular}

Aktivitas belajar siswa dalam pembelajaran pada setiap siklusnya semakin lebih baik selama diterapkannya model pembelajaran cooperative learning tipe group investigation berbasis multimedia. Aktivitas belajar siswa tersebut semakin membaik karena setiap selesai kegiatan pembelajaran, guru melakukan diskusi bersama observer dengan tujuan meningkatkan aktivitas belajar siswa dalam pembelajaran pada siklus berikutnya. Aktivitas belajar siswa dalam melaksanakan setiap tahapan pembelajaran dengan model group investigation berbasis multimedia ini berangsur semakin membaik dan terjadi peningkatan pada setiap siklusnya dari kategori tinggi sampai sangat tinggi.

Keterlaksanaan model adalah tahapan dalam pembelajaran yang harus dilalui agar proses pembelajaran dapat mencapai tujuan sesuai dengan yang diinginkan. Hasil observasi terhadap keterlaksanaan model (Tabel 4) merupakan data yang diambil dari lembar observasi aktivitas guru yang diisi oleh observer.

Tabel 4. Perkembangan Keterlaksanaan Model

\begin{tabular}{ccc}
\hline Siklus & $\begin{array}{c}\text { Persentase Keterlaksanaan } \\
\text { Model }\end{array}$ & Kategori \\
\hline I & 60,29 & Sedang \\
\hline II & 79,41 & Baik \\
\hline III & 88,23 & Sangat Baik \\
\hline
\end{tabular}

Keterlaksanaan model pada siklus I termasuk dalam kategori sedang, hal tersebut dikarenakan guru mencoba beradaptasi dengan kondisi kelas dan model pembelajaran yang digunakan. Adanya refleksi pada siklus I membuat aktivitas guru mengalami peningkatan yang baik pada siklus II. Begitu pula dengan refleksi yang dilakukan pada siklus II membuat aktivitas guru mengalami peningkatan menjadi sangat baik pada siklus III. Hal tersebut terjadi dikarenakan guru sudah beradaptasi dengan kondisi kelas dan model pembelajaran cooperative learning tipe group investigation berbasis multimedia.

\section{PEMBAHASAN}

Hasil penelitian menunjukkan bahwa model pembelajaran dapat mempengaruhi hasil belajar siswa. Model pembelajaran yang digunakan dalam penelitian ini adalah model 
pembelajaran cooperative learning tipe group investigation berbasis multimedia pada mata pelajaran sistem pengaturan refrigerasi. Hasil belajar siswa aspek kognitif menunjukkan adanya peningkatan. Peningkatan hasil belajar ini dipengaruhi dengan adanya perbaikan proses pembelajaran pada setiap siklusnya. Perbaikan yang dilakukan yaitu dengan cara meningkatkan faktor-faktor yang mempengaruhi hasil belajar, baik itu faktor internal maupun eksternal. Guru berusaha untuk lebih dapat menarik minat dan memotivasi siswa sebagai upaya meningkatkan faktor internal. Sementara itu, upaya peningkatan faktor eksternal yang dilakukan adalah berupa penciptaan lingkungan yang kondusif, perencanaan pembelajaran yang matang, serta memberikan multimedia yang mendukung dan menarik. Upaya tersebut membuat hasil belajar siswa meningkat dari kategori belum lulus menjadi lulus baik.

Aktivitas belajar siswa saat diterapkannya model pembelajaran cooperative learning tipe group investigation berbasis multimedia meningkat pada setiap siklusnya. Aktivitas belajar siswa dengan jenis aktivitas fisik seperti membaca atau memperhatikan multimedia, mencatat, bertanya, menjawab, presentasi, mendengar, partisipasi, dan antusiasme dapat dilakukan dengan baik dan tertib. Aktivitas siswa pada siklus pertama memiliki kategori tinggi namun belum sepenuhnya terfokus untuk kegiatan pembelajaran dan juga siswa masih beradaptasi dengan model pembelajaran yang diterapkan oleh guru.

Aktivitas siswa pada siklus berikutnya menunjukkan adanya peningkatan, karena siswa sudah mulai beradaptasi dengan model pembelajaran yang diterapkan oleh guru dan juga peran guru yang telah dapat mengelola kelas dengan baik. Aktivitas siswa dalam pembelajaran menunjukkan sikap yang serius, berperan aktif dalam kelompok, antusias terhadap pembelajaran, memperhatikan multimedia dengan seksama pada tahap investigasi, serta proses evaluasi kelompok yang berjalan atraktif. Berdasarkan hasil pengamatan di atas, jelas bahwa model pembelajaran cooperative learning tipe group investigation berbasis multimedia dapat meningkatkan aktivitas belajar siswa.

Penerapan model pembelajaran cooperative learning tipe group investigation berbasis multimedia ini dapat dikatakan baik dan berhasil karena telah dapat meningkatkan hasil belajar siswa. Hal itu dikarenakan model pembelajaran ini memiliki kelebihan-kelebihan dalam proses pembelajarannya, seperti pada tahap investigasi yang menuntut siswa secara berkelompok untuk mencari informasi dan menganalisis topik berbantuan multimedia. Pembelajarannya mengutamakan kerja kelompok dari pada individual, sehingga siswa bekerja dalam suasana 
gotong royong dan mempunyai banyak kesempatan untuk menyalurkan informasi dan meningkatkan keterampilan berkomunikasi.

Keberhasilan penerapan model pembelajaran cooperative learning tipe group investigation berbasis multimedia yang telah dibahas di atas tidak terlepas dari faktor-faktor yang mempengaruhi hasil belajar. Faktor tersebut dapat ditingkatkan sehingga membuat hasil belajar dan aktivitas siswa meningkat. Faktor itu diantaranya adalah kondisi lingkungan yang kondusif, yang membuat siswa dapat berkonsentrasi belajar. Faktor lainnya adalah suasana pembelajaran yang aktif dan antusias ketika proses investigasi, karena suguhan multimedia pembelajaran yang diberikan oleh guru kepada setiap kelompok. Suasana ini berasal dari guru yang membangkitkan minat dan motivasi siswa, setelah itu guru mengarahkan suasana tersebut pada tujuan dari pembelajaran.

\section{KESIMPULAN}

Kesimpulan penelitian ini adalah penerapan model pembelajaran cooperative learning tipe group investigation berbasis multimedia pada mata pelajaran sistem pengaturan refrigerasi dapat meningkatkan hasil belajar siswa. Hal ini ditunjukkan dengan peningkatan nilai N-Gain pada setiap siklusnya. Aktivitas belajar siswa di dalam kelas selama diterapkannya model pembelajaran cooperative learning tipe group investigation berbasis multimedia mengalami peningkatan disetiap siklusnya. Model pembelajaran cooperative learning tipe group investigation berbasis multimedia ini memberikan hasil positif terhadap kegiatan pembelajaran karena dapat meningkatkan aktivitas siswa selama proses pembelajaran, sehingga siswa lebih aktif dan antusias dalam belajar.

\section{DAFTAR PUSTAKA}

Hamalik, O. (2003). Proses Belajar Mengajar. Jakarta: Bumi Aksara.

Kunandar. (2012). Langkah Mudah Penelitian Tindakan Kelas Sebagai Pengembangan Profesi Guru. Jakarta: PT. Raja Grafindo Persada.

Sahuri, U. (2010). Multimedia Pembelajaran. [Online]. Tersedia: http://sahuri-punk. blogspot.com/2010/12/multimedia-pembelajaran.html. [16 Maret 2013].

Slavin, R. E. (2010). Cooperative Learning: Teori, Riset, dan Praktik. Bandung: Nusa Media. 
Sudjana, N. (2005). Penilaian Hasil Proses Belajar Mengajar. Bandung: PT. Remaja Rosda Karya.

Syarifuddin. (2011). Pembelajaran Kooperatif Tipe GI (Group Investigation). [Online].Tersedia: http://syarifartikel.blogspot.com/2011/10/pembelajaran-kooperatiftipe-gi-group.html. [5 Maret 2013]

Warsita, B. (2008). Teknologi Pembelajaran Landasan dan Aplikasinya. Jakarta: Rineka Cipta.

Winataputra, U. S. (2001). Model-model Pembelajaran Inovatif. Jakarta: Direktorat Jenderal Pendidikan Tinggi Departemen Pendidikan Nasional. 